\title{
Özel Eğitim Öğretmen Adaylarının Öğretmenlik Mesleğine Yönelik Tutumlarını Yordayan Değişkenler
}

Osman Özokcu, Hatay Mustafa Kemal Üniversitesi, ORCID ID: 0000-0001-5631-0495

Öz

Bu araştırmada özel eğitim öğretmen adaylarının öğretmenlik mesleğine yönelik tutumlarını yordayan değişkenlerin belirlenmesi hedeflenmiştir. Araştırma nicel araştırma yöntemlerinden ilişkisel tarama modeli ile gerçekleştirilmiştir. Araştırmanın katılımcılarını, 308 (163 kadın, 145 erkek) özel eğitim öğretmen adayı oluşturmaktadır. Araştırma verileri Kişsisel Bilgi Formu, Akademik Motivasyon Ölçeği, Yaşam Doyumu Ölçeği, Mesleki Benlik Saygısı Ölçeği ve Öğretmen Öz Yeterlilik Ölçeği kullanılarak toplanmıştır. Verilerin analizinde, Pearson Korelasyon Katsayısı ve Hiyerarşik Regresyon analizi testleri kullanılmıştır. Araştırma sonuçları, öğretmen adaylarının tutumlarının mesleki benlik saygısı, motivasyonsuzluk, içsel motivasyon ve özyeterlilik değişkenleri tarafından yordandığı, yaşam doyumu ve dışsal motivasyon değişkenlerinin ise öğretmenlik mesleğine yönelik tutumun anlamlı birer yordayıcısı olmadığını göstermiştir. Bu bulgular doğrultusunda, özel eğitim öğretmen adaylarının öğretmenlik mesleğine yönelik tutumlarını geliştirebilecek ortamların oluşturulmasına yönelik öneriler geliştirilmiştir

Gönderim Tarihi :

Anahtar Kelimeler: Öğretmen adayı, tutum, akademik 28.07.2020 motivasyon, yaşam doyumu, mesleki benlik saygısı, öz yeterlilik

İnönü Üniversitesi

Eğitim Fakültesi Dergisi

Cilt 22, Sayı 1, 2021

ss. 01-28

DOI:

10.17679/inuefd. 775139

Önerilen Atıf

Kabul Tarih

03.02.2021

Özokcu, O. (2021). Özel eğitim öğretmen adaylarının öğretmenlik mesleğine yönelik tutumlarını yordayan değişkenler. Inönü Üniversitesi Eğitim Fakültesi Dergisi, 22(1), 01-28. DOI: 10.17679/inuefd.775139 


\title{
The Variables Predicting the Attitudes of Turkish Special Education Preservice Teachers Towards the Teaching Profession
}

\author{
Osman Özokcu, Hatay Mustafa Kemal University, ORCID ID: 0000-0001-5631-0495
}

\begin{abstract}
This study aimed to determine the variables predicting the attitudes of Turkish special education preservice teachers towards the teaching profession. The study was carried out using a relational screening model among the quantitative research methods. The participants of the study consisted of 308 (163 females, 145 males) special education preservice teachers. The research data were collected using the Personal Information Form, Academic Motivation Scale, Life Satisfaction Scale, Professional Self-Esteem Scale, and Teacher Self-Efficacy Scale. The Pearson correlation coefficient and hierarchical regression analysis tests were used to analyze the data. The results of the study demonstrated that the preservice teachers' attitudes were predicted by the variables of professional self-esteem, amotivation, intrinsic motivation, and self-efficacy, while the life satisfaction and extrinsic motivation variables were not significant predictors of attitudes towards the teaching profession. Based on these findings, it was suggested to create environments that could improve teaching profession of special education teacher candidates
\end{abstract}

Keywords: Preservice teacher, attitude, academic motivation, life satisfaction, professional self-esteem, self-efficacy
Inönü University

Journal of the Faculty of

Education

Vol 22, No 1, 2021

pp. 01-28

DOI:

10.17679/inuefd.775139

Suggested Citation

Received : 28.07.2020

Accepted : 03.02.2021

Özokcu, O. (2021). The Variables Predicting the Attitudes of Turkish Special Education Preservice Teachers Towards the Teaching Profession. Inonu University Journal of the Faculty of Education, 22(01), 01-28. DOI: 10.17679/inuefd.775139 


\section{The Variables Predicting the Attitudes of Turkish Special Education Preservice Teachers Towards the Teaching Profession}

The primary element of the education system is the student. The main element of the operation and success of this system, which is established to meet the basic requirements of students and to develop them at the maximum capacity, is the teacher. Even if all the other elements of education are perfectly met, if teachers do not have the necessary qualifications, or if there are obstacles in front of their efficient working in the profession and they have dissatisfaction and concerns about this, it is unlikely that this system will achieve success. Therefore, the primary and most important issue in the education system is to establish a good teacher training system. The efficient operation of the education system depends on equipping teachers, who operate the system, with adequate knowledge and skills. However, in achieving success, attitudes have also a significant impact as well as knowledge and skills.

The attitude is defined as an acquired internal situation that affects the individual's choice in individual activities against any group of things, individuals, events, and a wide variety of situations (Senemoğlu, 2005). In other words, it is psychologically the situation of directing, and being on the side or against the behaviors, thoughts, and feelings of an individual related to an object, person, situation, etc. (Semerci \& Semerci, 2004). From the point of view of education organizations, one of the most critical factors affecting teachers' satisfaction with their jobs and their levels of commitment to their profession is their attitudes towards the teaching profession. Teachers' attitudes towards the profession are reflected in their behaviors and classroom atmosphere and play a significant role in their students' personality development, in the quality of teacher-student relations, and the provision of learning (Semerci \& Semerci, 2004).

The pre-service period is particularly important for teachers to fulfill the requirements of the profession more effectively in the pre-service period and to gain positive attitudes towards their profession in order to become successful in their professions. It is of great 
importance to organize this period in a way that preservice teachers develop positive attitudes towards their profession in order for them to love their profession, become attached to it and become aware of the necessity and importance of their profession in social terms. Indeed, Küçükahmet (1976) stated that teachers' attitudes towards their profession were one of their most important personality traits affecting their students and that positive attitudes towards the profession, students and school work had a great impact on students' learning and personalities. Also, when preservice teachers are trained to possess a positive attitude, it is stated that they can be successful in their professional life, do their professions willingly and pleasurably, and show more positive attitudes towards their students (Çapri \& Çelikkaleli, 2008; Çeliköz \& Çetin, 2004; Johnson \& Howell, 2005; Oral, 2004; Ünlü, 2011; Üstüner, 2006). Therefore, to conduct current studies on determining the attitudes of preservice teachers and the variables affecting these attitudes is very important.

There are many variables which affect the attitudes of preservice teachers towards the teaching profession. These variables include preservice teachers' demographic characteristics, self-efficacy, professional self-esteem, life satisfaction, academic motivation, and many other factors. When the related literature is examined, it is noteworthy that there are many studies on this subject (Arslan \& Akyol, 2006; Bayrakdar et al., 2016, Çapri \& Çelikkaleli, 2008; Çapri \& Çelikkaleli, 2008; Ömür \& Nartgün, 2013; Özyürek \& Erbay, 2015). In this regard, this study aimed to investigate the variables predicting the attitudes of special education preservice teachers towards the profession.

Related studies demonstrate that preservice teachers' individual characteristics are effective on their attitudes towards the teaching profession (Çapa \& Çil, 2000; Çapri \& Çelikkaleli, 2008; Çeliköz \& Çetin, 2004; Oral, 2004; Şimşek, 2005; Üstüner et al., 2009). These studies have concluded that there is a relationship between the attitudes towards the profession and many variables such as preservice teachers' age, gender, type of the high 
school they graduated, education program, general academic achievement, and their reasons for choosing the profession.

The concept of self-efficacy was first defined by Bandura (1977) as the belief of individuals in their capacity to organize the activities and actions necessary to demonstrate a certain performance and to perform them successfully. Tschannen-Moran \& Woolfolk Hoy (2001) described teacher self-efficacy as their beliefs in that they would demonstrate the necessary behaviors to perform the teacher function successfully. Therefore, teachers' perceptions of their self-efficacy are considered to be one of the most important factors that directly affect teachers' teaching practices. Studies demonstrate that the self-efficacy beliefs of preservice teachers are a significant predictor of their attitudes towards their profession (Aydın \& Tenekeci, 2013; Bayrakdar et al., 2016; Karabulut et al., 2019; Çakır, Kan \& Sünbül, 2006; Çapri \& Çelikkaleli, 2008; Demirtaş, Cömert \& Özer, 2011; Kaufman \& Sawyer, 2004; Yavuz, 2020).

Another critical factor in the success and efficiency of preservice teachers in their profession in the future is professional self-esteem. Professional self-esteem is expressed as how important and valuable an individual considers his/her profession (Arıcak, 1999). Professional self-esteem is also considered as a prerequisite for professional satisfaction and compliance (Arıcak \& Dilmaç, 2003). Arıcak \& Dilmaç (2003) emphasize that while individuals with a profession compatible with their selfness are expected to be more successful and productive, individuals who have a profession incompatible with their selfness will have a high probability of experiencing conflict and dissatisfaction. When the results of the studies on the subject are examined, it has been concluded that there is a significant positive relationship between professional self-esteem and attitudes towards the profession (Arslan \& Akyol, 2006; Dilmaç et al., 2009; Girgin et al., 2010).

Motivation can be expressed as the internal situation that causes human behaviors to emerge and that directs the behaviors (Demir \& Arl, 2013). Intrinsic motivation is the reactions 
developed by an individual against intrinsic needs. Extrinsic motivation includes effects coming from the outside of an individual (Akbaba, 2006). Amotivation is the state of being reluctant to behave (Ryan \& Deci, 2000a). Amotivation may originate from not valuing a behavior or activity, from feeling inadequate to perform the behavior, or from believing that you cannot achieve what you want (Ryan \& Deci, 2000a). Academic motivation is defined, in short, as the production of the energy required for academic work (Bozanoğlu, 2004). While the concept of motivation has a multi-faceted, non-cognitive psychosocial structure, academic motivation is a more specific concept and is related to cognitive, behavioral and affective educational factors such as creative thinking skills, learning skills, satisfaction with the school, and reasons for continuing school (Deci \& Ryan, 2000). It is stated that students with a high academic motivation level can actively participate in the learning process, are willing to spend more effort on difficult learning tasks, and can use effective problem-solving strategies (Elliot, Mcgregor \& Gable, 1999; Saracaloğlu et al., 2009). While teachers with intrinsic motivation direct their behaviors with internal dynamics, teachers with extrinsic motivation direct to goaloriented activities (Ryan \& Deci, 2000b). On the other hand, students with low levels of motivation may prefer less effortful tasks, abandon their tasks more quickly in the face of difficulties, and exhibit academic behaviors such as impatience, instability and not enjoying the job performed (Colengelo, 1997). When studies relationship between preservice teachers' attitudes towards the profession and academic motivation levels are examined, academic motivation affects the attitude levels of preservice teachers (Acat \& Yenilmez, 2004; Ayık \& Ataş, 2014, Ömür \& Nartgün, 2013; Saracaloğlu \& Dinçer, 2009; Saracaloğlu et al., 2009; Şahin \& Çakar, 2011; Terzi et al., 2012).

Life satisfaction is defined as the individual's appraisement of his/her whole life positive in accordance with the criteria he/she has determined (Diener, Emmons, Larsen \& Griffin, 1985). At the same time, life satisfaction represents judgments about subjective wellbeing and quality of life, reached by an individual based on the facts in his/her life (Şahin, 
2008). Life satisfaction belief is one of the most important factors that individuals should own in order to be happy in their lives, to bring meaning to their life, and to have a high level of achieving personal goals (Sülen-Şahin, 2010). It is stated that individuals with high life satisfaction have stronger social relationships, perform better in business life, have higher organizational commitment and are happier people. Therefore, it is stated that individuals who are not satisfied with life will be unhappy and nervous individuals instead of being a good citizen and teacher in the future (Şimşek, 2011). When studies on life satisfaction are examined, studies that examine life satisfaction of teachers and preservice teachers in terms of different variables are encountered (Aydemir et al., 2015; Şahin, 2013; Telef, 2011; Özyürek \& Erbay, 2015). Furthermore, some studies examine the relationship between preservice teachers' attitudes towards the profession and life satisfaction (Recepoğlu, 2013; Sülen-Şahin, 2010; Şahin, Zade \& Direk, 2009). The research results demonstrate that the demographic characteristics of individuals do not have a significant effect on general life satisfaction and that personal tendencies and close relationships have more effect on explaining life satisfaction (Özyürek \& Erbay, 2015). Studies also demonstrated that life satisfaction affects the attitude levels of preservice teachers and that as life satisfaction increases, attitudes towards the teaching profession also increase (Özyürek \& Erbay, 2015; Recepoğlu, 2013; Şahin et al., 2009).

In the literature, there are many studies on the variables that affect attitudes towards the teaching profession. However, only two studies which investigate the attitudes of special education teachers or preservice teachers towards the teaching profession were encountered (Aydın \& Tekneci, 2013; Bayrakdar et al., 2016). In these studies, it is observed that the relationships between the attitudes of special education teachers or preservice teachers and self-efficacy and anxiety levels were examined. Studies on different variables (academic motivation and life satisfaction, professional self-esteem, self-efficacy, etc.) that affect the attitudes of special education preservice teachers towards the teaching profession were not 
encountered. Therefore, there is a need for studies on the variables that may affect the attitudes of special education preservice teachers. The fact that preservice teachers have a positive attitude towards the teaching profession can make them successful teachers in the future. In this context, it is thought that determining the relationships between special education preservice teachers' attitudes towards the teaching profession and different variables that affect attitudes can provide benefit to institutions that train teachers, to the Ministry of National Education, to school administrators, and teachers. Unlike the literature, this study aimed to reveal the role of special education preservice teachers' academic motivation, life satisfaction, professional self-esteem, and self-efficacy in predicting their attitudes towards the teaching profession. In line with this general objective, answers to the following questions were sought.

\section{Research questions}

1. Is there a relationship between the attitudes of special education preservice teachers and their academic motivations, life satisfaction, professional self-esteem, and selfefficacy?

2. Do academic motivation, life satisfaction, professional self-esteem, and selfefficacy levels of special education preservice teachers predict their attitudes?

\section{Study Design}

\section{Metodology}

In this study, the relational screening model was used in order to determine whether the academic motivations, life satisfaction, professional self-esteem, and self-efficacy of special education preservice teachers change together with their attitudes towards the teaching profession, and if there is a change, how this occurs (Mertens, 2014). Correlational studies that examine the relationship between variables and the effects of one or more variables on another variable (Mertens, 2014). 


\section{Study Group}

A total number of 308 specail education preservice teachers who were fourth-grade students studying at Anadolu, Gazi, Ankara, Bolu, İnönü University in Turkey, Faculty of Education, Special Education Departments. Participated in this study from five universities in Turkey. All of the universities involved in the study were public universities that followed the same special education teacher education program, offered by the Higher Education Council. 357 completed the survey returned and overall, 49 scales were excluded due to incorrect or incomplete answers; therefore, a total of 308 scales were included in the study. 163 (\%52.9) female and $145(\% 47.1)$ male preservice teachers participated in the study. The mean age of the preservice teachers who participated in the study was $M=22.22$ years and $S D=.92$ years.

\section{Data collection tools}

Personal Information Form: It was developed by the researcher in order to obtain demographic information of special education preservice teachers participating in the study. In the form, questions about the university, age, and gender of preservice teachers were included.

Attitude Towards the Teaching Profession Scale: In the study, the attitude scale developed by Üstüner (2006) was used in order to determine the attitudes of preservice teachers towards the teaching profession. The scale consists of 34 items in total reflecting the attitude towards the teaching profession. The highest score that can be taken from the attitude scale, which is a one-dimensional scale, is 170 , while the lowest score is 34 . The highness of the score obtained from the scale indicates a positive attitude towards the teaching profession, and the lowness of the score indicates a negative attitude. The criterion scale validity of the scale was stated as .89 , the coefficient of reliability related to score stability as .72, and the internal consistency coefficient as .93 (Üstüner, 2006). As a result of the analyses conducted in this study, the internal consistency coefficient of the scale was found to be .92 . 
Academic Motivation Scale: The scale was developed by Vallerand et al. (1992). The scale consisted of 28 items. It consists of a total of seven different dimensions, including three intrinsic motivation dimensions, three extrinsic motivation dimensions, and one amotivation dimension, and each dimension includes four items. These are intrinsic motivation to know, intrinsic motivation to accomplish, intrinsic motivation to move, extrinsic motivation to recognize, extrinsic motivation to self-proof, extrinsic motivation to regulate, and amotivation dimensions, respectively. As the seven sub-dimensions of the scale can be evaluated separately, it is also possible to calculate the total intrinsic motivation score by combining the sub-dimensions of intrinsic motivation which are intrinsic motivation to know, intrinsic motivation to accomplish, and intrinsic motivation to move. The same is also valid for extrinsic motivation. In this study, while analyzing the scale scores, they were evaluated within the framework of these three dimensions (intrinsic motivation, extrinsic motivation, and amotivation). The scores received from the subtests range between 4 and 28 . As the subscales are evaluated separately, the value close to 28 obtained from each subscale indicates that this dimension is high in the individual. The scale's adaptation into Turkish and validity and reliability study were performed by Karagüven (2012). The Cronbach's alpha reliability coefficient of the scale was determined to be 0.87 . The Cronbach's alpha values of the subdimensions were determined to be 0.79 for intrinsic motivation to know, 0.74 for intrinsic motivation to accomplish, 0.67 for intrinsic motivation to move, 0.79 for extrinsic motivation to recognize, 0.75 for extrinsic motivation to self-proof, 0.73 for extrinsic motivation to regulate, and 0.83 for the amotivation dimension. The Cronbach's alpha internal consistency coefficients of the scale, calculated for this study sample, were .89 for intrinsic motivation, .79 for extrinsic motivation, and .75 amotivation $(n=308)$

Life Satisfaction Scale: The scale developed by Diener et al. (1985) measures overall life satisfaction. It consists of five 7-point Likert-type items. In the original study, the reliability of the scale was determined to be .87 , and the criterion-dependent validity was determined to be 
.82. The highest score that can be obtained from the scale is 35 , while the lowest score is 5 , and the low score indicates low life satisfaction. Life Satisfaction Scale adapted in Turkish culture by Şimşek (2011). The Cronbach's alpha reliability coefficient of the Turkish version of the scale was calculated to be .87 . In this study, the internal consistency coefficient of the scale was found to be .82 .

Professional Self-Esteem Scale: The Professional Self-Esteem Scale, developed by Arıcak (1999), is used to measure the esteem attitudes of individuals who are aged 17 and over, who have preferred a profession and who are receiving vocational training or performing a profession, towards their profession. The scale consists of thirty 5-point Likert-type items. Of these items, 14 items include positive, and 16 items include negative statements. These items are rated as "Strongly Agree" 5, "Agree" 4, "Undecided" 3, "Disagree" 2, and "Strongly disagree" 1. Reverse scoring was performed for negative items. The Cronbach's alpha reliability coefficient of the scale was found to be .93 , and the test-retest reliability coefficient was found to be .90 . In this study, the internal consistency coefficient of the scale was found to be .91 .

Teacher Self-Efficacy Scale: The scale, of which original version was developed by Tschannen-Moran \& Hoy (2001), was adapted into Turkish by Çapa et al. (2005) and its validity and reliability studies were conducted by the mentioned researchers. The self-efficacy scale consists of 24 items and three sub-dimensions in total. These sub-dimensions are "Ensuring student participation," "Classroom management," and "Instructional strategies." The internal consistency coefficients calculated for each dimension are as follows: .82 for ensuring student participation, .84 for classroom management, .86 for instructional strategies, and .93 for the overall scale. The internal consistency coefficients obtained as a result of the analyses made in this study are as follows: .81 for ensuring student participation, .81 for classroom management, .80 for instructional strategies, and .91 for the overall scale. 


\section{Data collection}

In order to collect the research data, the heads of special education departments of universities were contacted, and necessary permission were received from relevant units of universities. Then, in the winter term of the 2017-2018 academic year, the questionnaire package was sent by mail to all of the preservice teachers who were fourth-grade students in the special education teaching programs at the Special Education Departments of Anadolu, Gazi, Ankara, Bolu and İnönü University Faculty of Education, by writing a letter explaining the aim of the study, the right to volunteer participation, and the time required to fill in the questionnaire package. Of these questionnaires, 357 were sent back by mail, and the data obtained from the 308 questionnaires, which were usable as a result of excluding the questionnaires which were not filled in appropriately and were not answered at all, were transferred to the computer environment.

\section{Data Analysis}

SPSS 21 package program was used to analyze the data of this study. To test the data in accordance with the purposes of the study, the Kolmogorov-Smirnov [K-S] test was used for testing the assumption of normality, and the Levene statistic was used for testing the homogeneity of the data set. The Kolmogorov-Smirnov test result indicated that the data were normally distributed [ $p .05]$, and the Levene test result indicated that the variances displayed a homogeneous distribution. The Pearson's product-moment correlation coefficient test was used to determine whether there was a significant relationship between the attitudes of special education preservice teachers towards the teaching profession and their academic motivations, life satisfaction, professional self-esteem, and self-efficacy. Hierarchical regression analysis was conducted to determine the predictive power of special education preservice teachers' academic motivations, life satisfaction, professional self-esteem, and selfefficacy upon their attitudes towards the teaching profession (Büyüköztürk, 2005). 


\section{Findings}

This section presents the results of the regression and correlation analyses regarding preservice special education teachers' teaching profession and independent variables.

\section{Table 1}

Correlation Between Preservice Teachers' Attitudes Towards The Teaching Profession And Their Academic Motivations, Life Satisfaction, Professional Self-Esteem, And Self-Efficacy

\begin{tabular}{lccccccc}
\hline & 1 & 2 & 3 & 4 & 5 & 6 & 7 \\
\hline 1.Attitude & 1 & & & & & & \\
2.Intrinsic motivation & $.34^{* *}$ & 1 & & & & & \\
3.Extrinsic motivation & $.25^{* *}$ & $.61^{* *}$ & 1 & & & & \\
4.Amotivation & $-.41^{* *}$ & $-.21^{* *}$ & $-.20^{* *}$ & 1 & & & \\
5.Life Satisfaction & $.26^{* *}$ & $.21^{* *}$ & $.18^{* *}$ & $-.17^{* *}$ & 1 & & \\
6.Professional Self-Esteem & $.49^{* *}$ & $.27^{* *}$ & $.24^{* *}$ & $-.43^{* *}$ & $.25^{* *}$ & 1 & \\
7.Self-Efficacy & $.36^{* *}$ & $.24^{* *}$ & $.15^{* *}$ & $-.13^{*}$ & $.34^{* *}$ & $.31^{* *}$ & 1 \\
\hline$* * \mathrm{p}<.011^{*} \mathrm{p}<.05$ & & & & & & &
\end{tabular}

$* * p<.01, * p<.05$

When the correlations between preservice teachers' attitudes towards the profession and their academic motivations, life satisfactions, professional self-esteem, and teacher selfefficacy in Table 1 are examined, it is observed that the values vary between -.41 and .61 . There is a significant low positive correlation between the attitude and intrinsic motivation $(r=$ $.34, p=<.01)$, between the attitude and extrinsic motivation $(r=.25, p=<.01)$, between the attitude and life satisfaction $(r=.25 p=<.01)$, between the attitude and professional selfesteem $(r=.49, p=<.01)$, and between the attitude and teacher self-efficacy $(r=.36, p=<$. 01). A low significant negative correlation was determined between the attitude and amotivation $(r=-.41, p=<.01)$.

When the results of the hierarchical regression analysis in Table 2 were examined, it was observed that the academic motivation variable in the first block significantly predicted the preservice teachers' attitude towards the teaching profession $[F(3-306)=32.573, p<.01, R$ $\left.=492, R^{2}=242, \Delta R^{2}=242\right]$. It was determined that among the subdimensions of academic motivation in the first block, intrinsic motivation $(\beta=.262, t=4.106, p<.01)$, extrinsic 
motivation $(\beta=.016, t=.258, p>.01)$, and amotivation $(\beta=-.355, t=-.6 .935, p<.01)$

contributed significantly to the total variance and the contribution was $24 \%$.

In the second block, after controlling the effects of the intrinsic motivation, extrinsic motivation, and amotivation variables, which are the sub-dimensions of the academic motivation variable, it was observed that life satisfaction significantly predicted the preservice teachers' attitude towards the teaching profession $\left[F(4-305)=27.227, p<.01, R=513, R^{2}=\right.$ $263, \Delta R^{2}=021$. It was found out that the life satisfaction variable entered in the second block contributed significantly to the total variance $(\beta=.150, t=2.954, p<.01)$ and explained $26 \%$ of the total variance.

In the third block, besides the academic motivation and life satisfaction variables entered into the first two models, professional self-esteem was added to the model. In the third block, after controlling the effect of other variables, it was observed that the professional self-esteem variable significantly predicted the preservice teachers' attitude towards the teaching profession $\left[F(5-304)=31.975, p<.01, R=587, R^{2}=345, \Delta R^{2}=082\right]$. It was found out that the professional self-esteem variable entered in the third block contributed significantly ( $\beta$ $=.328, \mathrm{t}=6.150, \mathrm{p}<.01)$ to the total variance and explained $35 \%$ of the total variance.

In the fourth and last block, besides the academic motivation, life satisfaction and professional self-esteem variables entered in the first three blocks, teacher self-efficacy was added to the model. In the fourth model, after controlling the effect of other variables, it was observed that the self-efficacy variable significantly predicted the preservice teachers' attitude towards the teaching profession $\left[F(6-303)=30.236, p<.01, R=612, R^{2}=375, \Delta R^{2}=030\right]$. It was found out that the teacher self-efficacy variable entered in the fourth block contributed significantly to the total variance $(\beta=.192, t=3.803, p<.01)$ and explained $38 \%$ of the total variance. 
Table 2

The Results Of Hierarchical Regression Analysis Related To Predicting The Attitude Towards The Teaching Profession

\begin{tabular}{|c|c|c|c|c|c|c|c|c|c|c|}
\hline Model & Variable & $\mathrm{R}$ & $\mathrm{R}^{2}$ & $\Delta R^{2}$ & $\mathrm{~B}$ & S.H. & $\beta$ & $\mathrm{t}$ & $\mathrm{F}$ & $p$ \\
\hline \multirow[t]{4}{*}{ Block1 } & & .492 & .242 & 242 & & & & & 32.573 & .000 \\
\hline & Intrinsic motivation & & & & .423 & .103 & .262 & 4.106 & & .000 \\
\hline & Extrinsic motivation & & & & .033 & .128 & .016 & .258 & & .796 \\
\hline & Amotivation & & & & -1.462 & .211 & -.355 & -6.935 & & .000 \\
\hline \multirow[t]{5}{*}{ Block 2} & & .513 & .263 & .021 & & & & & 27.227 & .000 \\
\hline & Intrinsic motivation & & & & .389 & .102 & .241 & 3.801 & & .000 \\
\hline & Extrinsic motivation & & & & .011 & .127 & .006 & .088 & & .930 \\
\hline & Amotivation & & & & -1.380 & .210 & -.335 & -6.570 & & .000 \\
\hline & Life Satisfaction & & & & .253 & .086 & .150 & 2.954 & & .003 \\
\hline \multirow[t]{6}{*}{ Block 3} & & .587 & .345 & .082 & & & & & 31.975 & .000 \\
\hline & Intrinsic motivation & & & & .321 & .097 & .198 & 3.293 & & .001 \\
\hline & Extrinsic motivation & & & & -.029 & .120 & -.014 & -.238 & & .812 \\
\hline & Amotivation & & & & -.887 & .214 & -.215 & -4.142 & & .000 \\
\hline & Life Satisfaction & & & & .172 & .082 & .102 & 2.095 & & .037 \\
\hline & $\begin{array}{l}\text { Professional Self- } \\
\text { Esteem }\end{array}$ & & & & .383 & .062 & .328 & 6.150 & & .000 \\
\hline \multirow[t]{7}{*}{ Block 4} & & .612 & .375 & .030 & & & & & 30.236 & .000 \\
\hline & Intrinsic motivation & & & & .273 & .096 & .169 & 2.837 & & .005 \\
\hline & Extrinsic motivation & & & & -.016 & .117 & -.008 & -.135 & & .893 \\
\hline & Amotivation & & & & -.916 & .210 & -.222 & -4.372 & & .000 \\
\hline & Life Satisfaction & & & & .087 & .083 & .052 & 1.047 & & .296 \\
\hline & $\begin{array}{l}\text { Professional Self- } \\
\text { Esteem }\end{array}$ & & & & .331 & .062 & .284 & 5.300 & & .000 \\
\hline & Self-Efficacy & & & & .368 & .097 & .192 & 3.803 & & .000 \\
\hline
\end{tabular}

\section{Discussion \& Conclusion}

In this study, to what extent special education preservice teachers' attitudes towards the teaching profession are predicted by the academic motivation (intrinsic, extrinsic motivation, and amotivation), life satisfaction, professional self-esteem, and self-efficacy variables was investigated. The results of the study revealed that all variables except for extrinsic motivation and life satisfaction, which are the sub-dimensions of academic motivation, are significant predictors of attitude towards the teaching profession. According to the results, all of the independent variables explained about $38 \%$ of the attitudes. The results of the hierarchical regression analysis demonstrated that the preservice teachers' attitudes were predicted by the professional self-esteem, amotivation, intrinsic motivation and self- 
efficacy variables, and life satisfaction and extrinsic motivation were not significant predictors of the attitudes towards the teaching profession.

A significant negative correlation was found between amotivation and preservice teachers' attitudes, while a positive significant correlation was found between intrinsic motivation and attitudes. In other words, an increase in amotivation adversely affects attitudes towards the profession and reduces the attitude towards the teaching profession, and an increase in intrinsic motivation increases attitudes towards the teaching profession. When the results of the previous studies on the subject are examined, it is observed that in general the relations between attitudes towards the teaching profession and the general academic motivation of teachers or preservice teachers were examined (Ayık \& Ataş, 2014; Ömür \& Nartgün, 2013; Saracaloğlu \& Dinçer, 2009). The results of previous studies demonstrate that there are significant positive relationships between the academic motivation of preservice teachers and their attitudes towards the profession. Studies indicate that intrinsically motivated students are more successful (Handerson-King \& Smith, 2006; Lin et al., 2003). At the same time, individuals with high intrinsic motivation can use different strategies to solve a problem and perform better in academic terms. It is known that individuals with intrinsic motivation are more satisfied with their vital activities, and their psychological structures are better (Grolnick \& Ryan, 1989; Ryan \& Deci, 2000). Aktürk (2012) stated that there is a positive correlation between the training of preservice teachers with high academic motivation during the learning process and their future professional performance. All these results give the impression that special education preservice teachers will do their professions with love and willingly, and at the same time, that they have created a suitable motivation source which is necessary to become a successful teacher in the future, prior to service. Another result of the study on academic motivation variables demonstrated that the extrinsic motivation of special education preservice teachers was not a significant predictor of their attitudes towards the profession. Similarly, Ömür \& Nartgün (2013) found out that the 
motivation levels of pedagogical formation students were not a significant predictor of their attitudes towards the profession.

The result that special education preservice teachers' life satisfaction is not a significant predictor of their attitudes towards the profession was obtained. In the 3rd block of hierarchical regression analysis, it was observed that life satisfaction significantly predicts preservice teachers' attitudes towards the profession with adding professional self-esteem to the analysis. However, after the addition of self-efficacy to the analysis in the fourth block, the life satisfaction variable did not become a significant predictor of attitudes towards teaching. This result demonstrates that self-efficacy is a stronger variable than life satisfaction in predicting attitudes towards the teaching profession. In the study, in which Özyürek \& Erbay (2015) investigated the relationship between pre-school teachers' attitudes towards the teaching profession and life satisfaction, they determined that there was a significant relationship between attitudes towards the teaching profession and life satisfaction. Recepoğlu (2013) determined that there was a moderately positive significant relationship between preservice teachers' life satisfaction and their attitudes towards the teaching profession and that life satisfaction predicted attitudes towards the teaching profession significantly. Şahin et al. (2009) found out that preservice teachers' life satisfaction predicts their attitudes towards the teaching profession significantly. When the results of this study are examined in general, and when the variables predicting the attitudes of special education preservice teachers are taken into consideration, it can be said that the variables of professional self-esteem, academic motivation level, and self-efficacy belief are stronger predictive variables than the life satisfaction variable.

Professional self-esteem is the most significant predictor of attitudes towards the teaching profession. This result of the study coincides with the results of previous studies on this subject (Arslan \& Akyol, 2006; Dilmaç et al., 2009; Girgin et al., 2010; Yalçın-Incik \& Kılıç, 2014). When the results of all these studies are examined in general, there is a positive and 
significant relationship between preservice teachers' professional self-esteem and attitudes towards the teaching profession. Professional self-esteem takes a significant place for teachers in considering their profession as important and valuable. Arıcak (1999) stated that professional self-esteem is a prerequisite for the individual's professional harmony and satisfaction and that those who attribute a high level of value to their profession will be more successful in their profession.

A significant positive correlation was found between the self-efficacy beliefs of preservice teachers and their attitudes towards the profession. This result is similar to the results of the studies demonstrating that the self-efficacy of preservice teachers is related to their attitudes towards the teaching profession (Bayrakdar et al., 2016; Çapri \& Çelikkaleli, 2008; Demirtaş et al., 2011; Kanadlı, 2017; Oğuz \& Topkaya, 2008; Yalçın-İncik \& Kılıç, 2014). When the results of previous studies are examined in general, a significant positive relationship between self-efficacy and attitude towards the teaching profession was determined. Diken (2006) found out that special education preservice teachers found themselves sufficient to work with students with special needs, and that there was a significant positive relationship between their self-efficacy beliefs and their attitudes towards the inclusion of students with special needs. Diken \& Özokçu (2004) obtained the result that the experience of working with students with special needs increases teachers' self-efficacy beliefs. Studies demonstrate that preservice teachers gain a significant portion of their qualifications during the undergraduate period (Mulholland \& Wallace, 2001; Wolfolk-Hoy \& Burke-Spero, 2005). Furthermore, teaching practices are stated to provide the most significant contribution to the development of self-efficacy of preservice teachers (Tschannen-Moranet al., 1998; Wolfolk-Hoy \& Burke-Spero, 2005). Therefore, teaching practices that special education preservice teachers performed for two semesters may have increased their selfefficacy. All these results indicate that increasing the self-efficacy levels of special education preservice teachers will also increase their attitudes towards the profession. 
The results of the study revealed that all variables except for extrinsic motivation and life satisfaction, which are the subdimensions of academic motivation, were a significant predictor of the attitudes of special education preservice teachers. Some suggestions have been developed in the light of the results obtained in the study. Special education preservice teachers consider that their professional self-perceptions, academic motivations, and selfefficacy are significant predictors of their attitudes towards the profession. Therefore, it is possible to review the content and conduct of the courses which aim to improve the attitudes of preservice teachers towards the teaching profession and to train more qualified professionals in teacher training programs. In these courses, the subjects which are related to developing preservice teachers' perceptions of self-efficacy, professional self-esteem, intrinsic motivation, and life satisfaction positively, and thus gaining positive attitudes towards the profession, may be dealt predominantly. In addition to the theoretical knowledge about teaching methods, arrangements should be made to increase the practical experience of preservice teachers. Thus, preservice teachers may have the desired qualifications in terms of attitudes, knowledge, and skills, and it could be contributed to the training and employment of individuals who can practice the teaching profession more professionally. Moreover, various suggestions can be made for researchers, who are interested in the subject, within the framework of the results and limitations of the study. First of all, it will be useful to test the results of the study over different sample groups. The results of this study reflect the indirect observation obtained through the scales. By conducting qualitative studies on the subject, a study, which will reveal the attitudes of special education preservice teachers towards the profession more in depth, can be carried out. Besides, to conduct longitudinal studies examining the change in the attitudes of preservice teachers towards the profession can be recommended. In addition to these, studies can be designed in order to determine the factors which increase the intrinsic motivation and reduce the amotivation of preservice teachers. 


\section{References}

Acat, B., \& Yenilmez, K. (2004). Eğitim fakültesi öğrencilerinin öğretmenlik mesleğine ilişkin motivasyon (güdülenme) düzeyleri ve sorunları [Motivation levels of education faculty students in the teaching profession]. Manas University Journal of Social Sciences, 12, $125-140$.

Akbaba, S. (2006). Eğitimde motivasyon. [Motivation in education]. Kazım Karabekir Eğitim Fakültesi Dergisi, 13, 343-361.

Aktürk, O. A. (2012). Öğretmen adaylarının öğrenmeye ilişkin tutumlarının öğretmenlik mesleğini tercih etme nedenlerine ve akademik başarılarına göre incelenmesi [Analysis of attitudes of preservice teachers towards learning according to the reasons for choosing the teaching profession and their academic achivements]. Ahi Evran Üniversitesi Kırşehir Eğitim Fakültesi Dergisi ,13(3), 283-297.

Arıcak, O.T. (1999). Grupla psikolojik danışma yoluyla benlik saygısı ve mesleki benlik saygısının geliştirilmesi [Group counselling and professional self esteem through self Improvement]. An unpublished PhD Thesis. Marmara University, Institute of Education Sciences, Istanbul.

Arıcak, T., \& Dilmaç, B. (2003). Psikolojik danışma ve rehberlik öğrencilerinin bir takım değişkenler açısından benlik saygısı ile mesleki benlik saygısı düzeylerinin incelenmesi [An investigation on self-esteem and vocational self-esteem of counseling and guidance students]. Trakya University Journal of Social Science, 3(1), 1-7.

Aslan, D., \& Akyol, A.K. (2006). Okul öncesi öğretmen adaylarının öğretmenlik mesleğine yönelik tutumları ve mesleki benlik saygılarının incelenmesi [Investigation of preschool prospective teachers attitudes towards teaching profession and vocational self esteem]. Ç.Ü. Sosyal Bilimler Enstitüsü Dergisi, 1(2),51-60.

Aydemir, H., Diken, İ., K., Yıkmış, A., Aksoy, V., \& Özokçu, O. (2014). Özel eğitim alanında çalışan öğretmenlerin tükenmişlik düzeyleri ve yaşam doyumlarının incelenmesi [The 
burnout and life satisfaction of teachers working with students with special needs]. Abant İzet Baysal Üniversitesi Eğitim Fakültesi Dergisi, 15(Special issue), 68-86.

Aydın, A., \& Tenekeci, E. (2013). Zihin engelliler öğretmenliği öğrencilerinin öğretmenlik mesleğine yönelik tutumları ile kaygı düzeyleri [Special education prospective teachers anxiety levels and their attitudes towards teaching profession]. Pegem Eğitim ve Öğretim Dergisi, 3 (2), 1-12.

Ayık, A., \& Ataş, Ö. (2014). The relationship between pre-service teachers' attitudes towards the teaching profession and their motivation to teach. Journal of Educational Sciences Research,4(1), 25-43. https://doi.org/10.12973/jesr.2014.41.2

Bandura, A. (1977). Self-efficacy: Toward a unifying theory of behavioral change. Psychological Review, 84, 191-215. https://doi.org/10.1037/0033-295X.84.2.191

Bayrakdar, U., Vural Batık, M., \& Barut, Y. (2016). Özel eğitim öğretmen adaylarının öğretmen özyeterlik düzeyleri ve öğretmenlik mesleğine yönelik tutumları [The teacher selfefficacy of special education prospective teachers and their attitudes towards teaching profession]. Journal of Kırsehir Education Faculty, 17(2), 133-149.

Bozanoğlu, ì. (2004). Akademik Güdülenme Ölçeği: Geliştirmesi, Geçerliği, Güvenirliği. [Academic Motivation Scale: Development, Reliability, Validity]. Ankara Üniversitesi Eğitim Bilimleri Fakültesi Dergisi, 2, 83-98. https://doi.org/10.1501/Egifak_0000000094

Büyüköztürk, Ş. (2005). Sosyal bilimler için veri analizi el kitabı. [Statistic for social sciences]. Pegem A Yayıncilık.

Çakır, O., Kan, A., \& Sünbül, O. (2006). Öğretmenlik meslek bilgisi ve tezsiz yuksek lisans programlarının tutum ve özyeterlik açısından degerlendirilmesi [The evaluation of the teaching certificate program and the masters program without thesis with respect to students' attitudes and self-efficacy]. Mersin Universitesi Egitim Fakultesi Dergisi, 2(1), 36-47. 
Çapa, Y., Çakıroğlu, J., \& Sarıkaya, H. (2005). The development and validation of a Turkish version of the teachers sense of efficacy scale. Education and Science, 30(137), 74-81.

Çapa, Y., \& Çil, N. (2000). Öğretmen adaylarının öğretmenlik mesleğine yönelik tutumlarııın farklı değişkenler açısından incelenmesi [The attitudes of pre-service teachers towards teaching profession with regard to different variables]. Hacettepe University Journal of Education, 18, 69-73.

Çapri, B., \& Çelikkaleli, O. (2008). Öğretmen adaylarının öğretmenliğe ilişkin tutum ve mesleki yeterlik inançlarının cinsiyet, program ve fakültelerine göre incelenmesi [Investigation of preservice teachers' attitudes towards teaching and professional self-efficacy beliefs according to their gender, programs, and faculties]. Inonu Universitesi Egitim Fakultesi Dergisi, 9(15), 33-53.

Deci, E. L., \& Ryan, R. M. (2000). The "what" and "why" of goal pursuits: human needs and the self-determination of behavior. Psychological Inquiry, 11, 227-268. https://doi.org/10.1207/S15327965PLI1104_01

Demir M.K., \& Arı E. (2013). Öğretmen adaylarının akademik güdülenme düzeylerinin çeşitli değişkenler açısından incelenmesi [Assessing levels of academic motivation of preservice teachers in terms of various variables]. Eğitimde Kuram ve Uygulama, 9(3): 265-279.

Demirtaş, H., Cömert, M., \& Özer, N. (2011). Pre-service teachers' self-efficacy beliefs and attitudes towards profession. Education and Science, 36(159), 96-111.

Diener, E., Emmons, R. A., Larsen, R. J., \& Griffin, S. (1985). The satisfaction with life scale. Journal of Personality Assessment, 49(1), 71-75. https://doi.org/10.1207/s15327752jpa4901_13

Diken, i. (2006). Preservice teachers' efficacy and opinions toward inclusion of students with mental retardation. Eurasian Journal of Educational Research, 23, 72-81. 
Diken, İ. H., \& Özokçu, O. (2004). Examining Turkish teachers' sense of efficacy: an international perspective, American Educatinoal Research Association (AERA) Aannual Meeting, San Diego, CA, USA.

Dilmaç, B., Çıkılı, Y., Işık, H., \& Sungur, C. (2009). Teknik öğretmen adaylarının öğretmenlik mesleğine yönelik tutumlarının yordayıcısı olarak mesleki benlik saygısı [Technical teacher candidates' vocational self-esteem as predictor of attitudes related teaching prefessions]. Selçuk Üniversitesi Teknik Bilimler Meslek Yüksekokulu Teknik-Online Dergi, 8(2), 127-143.

Elliot, A., McGregor, H., \& Gable, S. (1999). Achievement goals, study strategies, and exam performance: A mediational analysis. Journal of Educational Psychology, 91, 549-563. https://doi.org/10.1037/0022-0663.91.3.549

Girgin, G., Özyılmaz Akamca, G., Ellez, A. M., \& Oğuz, E. (2010). Okul öncesi öğretmen adaylarının öğretmenlik mesleğine yönelik tutumları, mesleki benlik saygıları ve mesleki yeterlilik inançları [Preschool teacher candidates' attitudes towards profession, self efficacy beliefs and professional self respects]. Buca Eğitim Fakültesi Dergisi, 28, 1-15.

Grolnick, W.S., \& Ryan, R.M. (1989). Parent styles associated with children's self-regulation and competence in school. Journal of Educational Psychology, 81, 143-154. https://doi.org/10.1037/0022-0663.81.2.143

Henderson-King, D., \& Smith, M. (2006). Meanings of education for university students: Academic motivation and personal values as predictors. Social Psychology of Education, 9(2), 195-221. https://doi.org/10.1007/s11218-006-0006-4

Johnson, G., \& Howell, A. (2005). Attitude toward instructional technology following required versus optional WebCT usage. Journal of Technology and Teacher Education, 13(4), 643-654. 
Kanadlı, S. (2017). Prospective teachers' professional self-efficacy beliefs in terms of their perceived autonomy support and attitudes towards the teaching profession: A mixed methods study. Educational Sciences: Theory \& Practice, 17, 1847-1871. https://doi.org/10.12738/estp.2017.5.0597

Karabulut, A., Yandı, A. \& Kaya, A. (2019). Özel eğitim bölümünde öğrenim gören öğretmen adaylarının öz yeterlik inançlarının belirlenmesi. Turkish Journal of Social Research. 23(2), 555-574

Karagüven, M. H. (2012). Akademik motivasyon ölçeğinin Türkçe'ye adaptasyonu [The adaptation of academic motivation scale to Turkish]. Educational Sciences: Theory \& Practice, 12(4), 2599-2620.

Kaufman, R., S., E., \& Sawyer, B. E. 2004. Primary-Grade teachers' self-efficacy beliefs, attitudes toward teaching and discipline and teaching practice priorities in relation to the responsive classroom approach. The Elementary School Journal; 104 (4), 322-323.

Küçükahmet, L. (1976). Öğretmen yetiştiren kurum öğretmenlerinin tutumları [The Attitudes of Teacher Training Teachers]. Ankara Üniversitesi Eğitim Fakültesi Yayınları.

Lin, Y. G., McKeachie, W. J., \& Kim, Y. C. (2003). College student intrinsic and/or extrinsic motivation and learning. Learning and Individual Differences, 13(3), 251-258. https://doi.org/10.1016/S1041-6080(02)00092-4

Mertens, D. M. (2014). Research and evaluation in education and psychology: Integrating diversity with quantitative, qualitative, and mixed methods. Sage Publications.

Mulholland, J., \& Wallace, J. (2001). Teacher induction and elementary science teaching: Enhancing self efficacy. Teaching and Teacher Education, 17(2), 243-261. https://doi.org/10.1016/S0742-051X(00)00054-8

Oğuz, A., \& Topkaya, N. (2008). Ortaöğretim alan öğretmenliği öğrencilerinin öğretmen öz yeterlilik inançları ile öğretmenliğe ilişkin tutumları [Secondary education non- thesis 
graduate program students' self-efficacy beliefs and attitudes toward teaching profession]. Akademik Bakış, 14, 23-36.

Oral, B. (2004). Eğitim fakültesi öğrenilerinin öğretmenlik mesleğine ilişkin tutumları [The attitudes of students in the Faculty of Education towards the profession of teaching]. Eğitim Araştırmaları Dergisi, 15 (4),88-98.

Ömür, Y. E., \& Nartgün, Ş. S. (2013). Öğretmen adaylarının öğretmenlik mesleğine ilişkin tutumları ile yaşam doyumları arasındaki ilişkinin incelenmesi [Relationship between prospective teachers' attitudes towards teaching profession and their motivation levels]. Eğitimde Politika Analizi, 2 (2), 41-55.

Özyürek, A., \& Erbay, F. (2015). Okul Öncesi Öğretmenlerinin Öğretmenlik Tutumları Ille Yaşam Doyumları Arasındaki Iliş̧inin İncelenmesi [The investigation of relationship between teaching attitudes and life satisfaction of preschool teachers]. Çankırı Karatekin Üniversitesi Sosyal Bilimler Enstitüsü Dergisi, 6, 31-48.

Ryan, R. M., \& Deci, E.L. (2000a). Intrinsic and extrinsic motivations: Classic definitions and new directions. Contemporary Educational Psychology, 25, 54-67. https://doi.org/10.1006/ceps.1999.1020

Ryan, R.M., \& Deci, E.L. (2000b). Self-determination theory and the facilitation of intrinsic motivation, social development, and well-being. American Psychologist, 55, 68-78. https://doi.org/10.1037/0003-066X.55.1.68

Recepoğlu, E. (2013). Öğretmen adaylarının yaşam doyumları ile öğretmenlik mesleğine ilişkin tutumları arasındaki ilişkinin incelenmesi [Analyzing the relationship between prospective teachers' life satisfaction and attitudes concerning teaching profession]. Hacettepe Üniversitesi Eğitim Fakültesi Dergisi,1, 311-326.

Saracaloğlu A.S. ,\& Dinçer B. (2009). A study on correlation between self-efficacy and academic motivation of prospective teachers. Procedia Social and Behavioral Sciences,1, 320325. https://doi.org/10.1016/j.sbspro.2009.01.060 
Saracaloğlu, A.S., Kumral , O., \& Kanmaz, A. (2009). Ortaöğretim sosyal alanlar öğretmenliği tezsiz yüksek lisans öğrencilerinin öğretmenlik mesleğine yönelik yeterlikleri kaygıları ve akademik güdülenme düzeyleri [Anxieties, academic motivation levels and competencies at teaching profession of students at secondary education fields teaching nonthesis master program]. Yüzüncü Yıl Üniversitesi Eğitim Fakültesi Dergisi, $4(2), 38-54$.

Senemoğlu, N. (2005). Gelişim, öğrenme ve öğretim: Kuramdan uygulamaya [Development, learning and teaching: From theory to the practice]. Pegem A Akademi.

Semerci, N., \& Semerci, Ç. (2004). Türkiye'de öğretmenlik tutumları [The teacher attitudes in Turkey]. Fırat Üniversitesi Sosyal Bilimler Dergisi, 14(1), 137-146.

Sülen Şahin, F. (2010). Teacher candidates' attitudes towards teaching profession and life satisfaction levels. Procedia Social and Behavioral Sciences, 2:5196-5201. https://doi.org/10.1016/j.sbspro.2010.03.845

Şahin, Ş. (2008). Beden eğitimi öğretmenlerinin tükenmişlik ve yaşam doyumu düzeyleri [Levels of burnout and life satisfaction physical education teachhers].Yayımlanmamış Yüksek Lisans Tezi, Mersin Üniversitesi, Eğitim Bilimleri Enstitüsü, Mersin.

Şahin, ì. (2013). Öğretmenlerin iş doyumu düzeyleri [Job satisfaction levels of teachers]. Yüzüncü Yı Üniversitesi Eğitim Fakültesi Dergisi, 10 (1):142-167.

Şahin, H., \& Çakar, E. (2011). Eğitim fakültesi oğrencilerinin öğrenme stratejileri ve akademik güdülenme düzeylerinin akademik başarıya etkisi [The effects of students' academic motivation and students' learning strategies on students' success]. Journal of Turkish Educational Sciences, 9(3), 519-540.

Şahin, F. S., Zade, B. M. \& Direk, H. (2009). Öğretmen adaylarının öğretmenlik mesleğine yönelik tutum ve yaşam doyum düzeyleri [Prospective teachers' life satisfaction and attitudes concerning teaching profession]. Ulusal Eğitim Bilimleri Kurultay'ında sunulan bildiri, Ege Üniversitesi, İzmir. 
Şimşek, H. (2005). Ortaöğretim alan öğretmenliği tezsiz yüksek programina devam eden öğrencilerin öğretmenlik mesleğine yönelik tutumları[Prospective branch teachers' attitudes concerning teaching profession]. Yüzüncü Yıl Üniversitesi, Elektronik Eğitim Fakültesi Dergisi, 2(1), 1-26.

Şimşek, E. (2011). Örgütsel iletişim ve kişilik özelliklerinin yaşam doyumuna etkileri [The effects of organizatıonal communication and personality traits on life satisfaction]. Doktora Tezi. Anadolu Üniversitesi Sosyal Bilimler Enstitüsü, Eskişehir.

Telef, B.B. (2011). Öğretmenlerin öz-yeterlikleri, iş doyumları, yaşam doyumları ve tükenmişliklerinin incelenmesi [The study of teachers' self-efficacy, job satisfaction, life satisfaction and burnout]. ilköğretim Online, 10 (1), 91-108.

Tschannen-Moran, M., Woolfolk-Hoy, A., \& Hoy, W. K. (1998). Teacher efficacy: Its meaning and measure. Review of Educational Research, 68(2), 202-248. https://doi.org/10.3102/00346543068002202

Tschannen-Moran, M., \& Woolfolk-Hoy, A. (2001). Teacher efficacy: Capturing an elusive construct. Teaching and Teacher Education, 17, 783-805. https://doi.org/10.1016/S0742-051X(01)00036-1

Terzi, M., Ünal., M., \& Gürbüz., M.Ç. (2012). ilköğretim matematik öğretmen adaylarııın matematiğe yönelik akademik güdülenme düzeylerinin bazı değişkenler açısından incelenmesi. [Investigation of some variables of Primary mathematic prospective teachers academic motivation levels]. 10. Matematik Sempozyumu. Işık Üniversitesi, İstanbul.

Ünlü, H. (2011). Beden eğitimi öğretmenliği mesleğine yönelik tutum ölçeği [Developing an attitude scale for the profession of physical education teaching] geliştirilmesi. Kuram ve Uygulamada Eğitim Bilimleri, 1(4), 2005-2020.

Üstüner, M. (2006). Reliability and validity study of an attitude scale of teaching profession. Educational Administration: Theory and Practice, 12(45), 109-127. 
Üstüner, M., Demirtaş, H., \& Cömert, M. (2009). The attitudes of prospective teachers towards the profession ofteaching: The case of İönü University, Faculty of Education. Education and Science, 34(151), 140-155.

Vallerand, R. J., Pelletier, L. G., Blais, M. R., Briere, N. M., Senecal, C., \& Vallieres, E. F. (1992). The Academic Motivation Scale: A measure of intrinsic, extrinsic, and amotivation in education. Educational and psychological measurement, 52(4), 1003-1017. https://doi.org/10.1177/0013164492052004025

Yalçın-İncik, E., \& Kılıç, E. (2014). Attitudes regarding the teaching profession, professional efficacy beliefs and vocational self-esteem of teacher canditates enrolled at education faculties and pedagogic formation programmes. International Journal of Social Sciences \& Education, 4(2), 380-391.

Yavuz M . (2020). Özel eğitim okullarında çalışan öğretmenlerin mesleki öz-yeterlilik düzeylerinin çeşitli değişkenler açısından incelenmesi. Mehmet Akif Ersoy Üniversitesi Eğitim Fakültesi Dergisi. (55): 1-25

İletişim/Correspondence Dr. Öğr. Üyesi Osman ÖZOKCU ozokcu@gmail.com 